\title{
THE CONCEPT OF CONSTITUTIONAL FREEDOM OF A PERSON TO CONDUCT ENTREPRENEURIAL ACTIVITY
}

\author{
Serhii Penkov' ${ }^{1}$ Mykola Chabanenko²
}

\begin{abstract}
The article studies the concept and features of the constitutional freedom of a natural person to conduct business activity in Ukraine. It is analysed features of human freedom under consideration. The authors present their own definition of the constitutional freedom of a person to conduct entrepreneurial activity. The issue of peculiarities of management of a natural person as a business entity is considered. It compares the legal status of a natural person with the legal status of a private entrepreneur. The article lists the duties of a private entrepreneur, as well as limitations on the performance of any types of activities by private entrepreneurs. It considers a procedure of the state registration of a private entrepreneur. The paper defines the essence and main range of tools of mechanisms of state regulation of entrepreneurial activity in Ukraine. The issue of mechanisms regulation is covered. It is formed the principal functions, tools, and methods which the state follows in regulating entrepreneurship. The role of the state in managing the economy and functioning of business entities is discovered. The international experience of state business regulation is described. Statistics are indicated, and specific examples of countries are formed. Lines for handling problems concerning stimulating small and medium-sized enterprises are specified. Based on the analysis, generalization and systematization of research papers, and also weaknesses of government regulation of entrepreneurship in Ukraine are presented. The authors draw conclusions and propose ways for improving government regulation in order to improve and develop entrepreneurship in Ukraine. Theoretical approaches to the determination of the concept of the subject of offences counteraction are presented. Definition of the subject of offences counteraction in the sphere of entrepreneurial activity is analysed, and a range and system of the mentioned subjects are specified. Subjects of offences counteraction in the sphere of entrepreneurial activity vested with administrative and jurisdictional powers are put into an individual group.
\end{abstract}

Key words: guarantees of constitutional freedom, government regulation of entrepreneurship, constitutional freedom, entrepreneurship, entrepreneurial activity, legal status, offences in entrepreneurial activity, offences counteraction, freedom of entrepreneurial activity, business entity.

JEL Classification: K10, K22, K38, R00, R30

\section{Introduction}

Human constitutional right and constitutional freedom of entrepreneurial activity are closely related but not alike. Every person has the right to conduct an entrepreneurial activity, which is not forbidden by law. Prohibition of certain types of entrepreneurial activity and restriction on entrepreneurial activity for particular categories of individuals by the current laws confirms their theoretical significance and the necessity of solving important practical tasks concerning a person's exercise of the constitutional freedom.

One of the most popular subjects of entrepreneurial activity is a natural person as a business entity. The topical issue is the differentiation of legal status of a natural person who carries out business activities or other activity in the economy into a legal status of a person as an entrepreneur and legal status as a natural person. Another problem is that today, in fact, there is no special legislative act, which would consolidate the legal status of a citizen-entrepreneur.

The problem of the human constitutional right and freedom of entrepreneurial activity was studied by theorists, constitutional lawyers, and economists. Among them, there are papers by E. A. Andriukhyn, T. V. Blashchuk, K. H. Boberskf, L. S. Yelizarova, D. V. Zadykhailo, A. V. Kovach, O. O. Kolomiiets, T. M. Kravtsova, L. O. Nikitenko, N. O. Sanyakhmetova, S. V. Riznyk, V. C. Shcherbynf, A. V. Shchuruk, and others. But despite a large number of publications, it should be noted that there is a deficiency of studying

Corresponding author:

${ }^{1}$ Dniprovskii University of the Humanities, Ukraine.

E-mail:mpv12@i.ua

${ }^{2}$ Dniprovskii University of the Humanities, Ukraine.

E-mail: uk_dgu@ua.fm 
and investigating the issue of citizens' participation in the economic and legal sphere. A range of important problems of a theoretical and practical nature are still unresolved. One of the problems is the lack of a single legislative act that would consolidate the specifics of the activity of a private entrepreneur and objective prohibitions and restrictions on conducting the entrepreneurial activity.

At the same time, the role of the state is significantly enhanced in modern society. This is manifested in various spheres of activity, in particular, in the elaboration of the system of regulatory and legal acts aimed at regulating the market, entrepreneurial activity, customs rules, banking activities, prices, wages, and social protection of the population. Government regulation of entrepreneurship is the state's influence on the activity of business entities, and its necessity is determined by the objectives of economic policy aimed at achieving sustainable development of the state and its regions, ensuring the constant growth of indicators characterising the level of well-being and quality of living standards in the country. The term "mechanism" is used in engineering where it means a device that transmits or converts the movement, and the meaning of this term is also associated with the internal structure of the machine. This word is used as the definition of the internal structure, the system of something and also it can be used for characteristics of the complex of states and processes, which form a certain phenomenon.

Issues of improving the mechanism of government regulation of entrepreneurial activity under the conditions of activation of the country's integration processes are priority tasks and require a comprehensive examination. There is a need to distinguish and generalise the terminology of "public administration" in the part concerning the concepts of regulation and government regulation of entrepreneurial activity. The determination of theoretical-methodological and practical principles of the formation and development of mechanisms of government regulation of entrepreneurial activity is an important scientific and practical task, which should be exercised by creating multifarious control mechanisms, their adaptation to the conditions of the external environment of enterprises operation.

\section{Constituent elements of constitutional freedom of a person to conduct entrepreneurial activity in Ukraine}

The current legislation of Ukraine doesn't have definitions for the concept "business entity - citizen". The Ukrainian legislation also has a lack of a unified terminological approach to the definition for the mentioned category of business entities, and it is used the following terms: "citizen as a business entity", "entrepreneur without the status of a legal entity", "citizen- entrepreneur", "private entrepreneur". It is noted that the use of several terms in relation to one concept deforms the will of the legislator, causes difficulties in the process of law applying, and negatively affects enforcement of the rights and interests of the participants of legal relations. And due to this fact, it is justified the introduction of terminological sameness regarding the identification of a person as a business entity and the use of "business entity - citizen" for the term because this term is most correct for the denomination of relations between an individual and the state (Vinnyk, 2017).

A private entrepreneur is a relatively new entity of economic law as entrepreneurial activity under a statecontrolled economy was banned and its legalization in Ukraine was carried out in accordance with the Law of Ukraine "On Entrepreneurship" (1991), which was repealed due to the entry into force of the Commercial Code of Ukraine (hereinafter referred to as CC of Ukraine). A citizen is recognized as a business entity if he/she conducts entrepreneurial activities on the basis of his/her state registration as an entrepreneur without the status of a legal entity. A citizen-entrepreneur is liable to the full extent of his/her assets in accordance with the law, which may impose a court-enforced collection on it (Art. 128 of CC of Ukraine (Hospodarskyi kodeks Ukrainy, 2003)). State registration of a particular natural person by making relevant records into the Unified State Register is a determinative component for gaining the status of an entrepreneur, including the agriculture sphere according to the Law of Ukraine "On State Registration of Legal Entities, Private Entrepreneurs and Public Formations. In accordance with Art. 18 of the Law, an entrepreneur has to submit the following documents for state registration of a private entrepreneur:

application on state registration of a private entrepreneur;

- application on simplified tax system for a natural person and/or a registration application for voluntary registration as a payer of value-added tax in the form approved by the central executive body, which ensures the formation of the state tax and customs policy at the request of an applicant;

- notarized written permission of parents (adoptive parents) either guardian or tutorship and guardianship authority for a person aged sixteen years and who has a desire to carry out entrepreneurial activity but doesn't have absolute civil capacity;

- agreement (declaration) on the formation of family farm enterprise, in a case of state registration of a natural person who establishes a family farm enterprise independently or together with family members according to the Law of Ukraine "On Farming Enterprise”.

The procedure for state registration of a private entrepreneur involves: checking the completeness of documents submitted to a public registrar and 
completeness of the information indicated in the registration record; verification of documents submitted to the state registrar for confirming a lack of grounds for refusal to conduct state registration; making entry about a private entrepreneur in the Uniform State Register; registration and issuance of an extract from the Uniform State Register. According to Art. 26 of the mentioned Law, examination of documents submitted for state registration and other registration actions is carried out within 24 hours after the receipt of documents submitted for state registration and other registration procedures (Pro fermerske hospodarstvo, 2003).

Legal status of a private entrepreneur is characterised by the availability of the following elements: official registration as a business entity, accounting in the bodies of the state fiscal service and the Pension Fund of Ukraine as a taxpayer and a Unified Contribution for Compulsory State Social Insurance respectively, production of a seal (if necessary), opening of a current account in a banking institution (as required), licensing application (in the case of provision of licensing types of activities).

According to objects of activity, a natural person can carry out: industrial entrepreneurial activity, that is, activity in the process of which certain goods are produced; non-production entrepreneurial activity, within which one distinguishes as follows: activity on work performance, rendering of services (conduct repairs, provision of information services, implementation of transportations); trading activity; other non-production activities, in particular, activities in the financial market.

A citizen-entrepreneur implements his/her activities according to the principles of freedom of enterprise and fundamentals provided by Art. 44 of the CC of Ukraine. A citizen-entrepreneur implements his/her activities according to the principles of freedom of enterprise. In addition, entrepreneurship is considered as independent, initiative, systematic, at one's own risk, legal activities on goods production, work performance, rendering of services, trading activity with a view to gain a benefit. Citizens of Ukraine, citizens of other states, stateless persons can conduct business but it is limited to deputies, servants and officials of government and local self-government bodies, servicemen, personnel of prosecution service, court, state security, etc. An entrepreneur is obliged:

- to obtain a license for conducting peculiar types of business activities according to cases and procedure prescribed by the law;

- to notify the state registration authority of the change of his/her address indicated in the registration documents, objects of activity, other essential conditions of his/her business, which must be specified in the registration documents; to adhere to the rights and legitimate interests of consumers, ensure the required quality of the goods (works, services) that they produce, observe the rules of mandatory certification of products, established by law; - to prevent unfair competition, other violations of anti-monopoly and competition legislation;

- to keep records of business performance in accordance with the requirements of the legislation;

- to provide the bodies of revenues and duties with a declaration of property status and income (tax return), other relevant information for tax charges and other mandatory payments in due time; to pay taxes and other obligatory payments in the form and in the amount set forth by the law (p. 6 of Art. 128 of the CC of Ukraine) (Pro fermerske hospodarstvo, 2003).

The Constitution of Ukraine states about the right to carry out business activity which is not forbidden by the law (Konstytutsiia Ukrainy, 1996) that is quite equivocal: entrepreneurial activity cannot be prohibited because such activity is socially useful in a market society, and the state can only impose restrictions on the implementation of its individual types or certain subjects. Due to the fact that Ukraine hasn't any unified legislative act, which would set objective bans on business performance, there are many negative developments in the business area. The legislation includes restrictions on the performance of certain types of activities by private entrepreneurs. It is referred to activities involving the distribution of narcotic drugs, psychotropic substances, their analogues and precursors; activities related to the protection of certain high-security objects of state property law, as well as activities involving forensic, medical, forensic psychiatric examinations and the development, testing, production, and operation of carrier rockets including their space launches for any purpose; activities involving the production of composite motor petrol or with the addition (combination) of bioethanol and/or bio-components on bioethanol base to the hydrocarbon base (gasoline, distillations, components, etc.); activities involving the production of bioethanol (Article 4 of the Law of Ukraine "On Entrepreneurship") (Pro pidpryiemnytstvo, 1991).

\section{Mechanism of government regulation of constitutional freedom of a person to conduct entrepreneurial activity in Ukraine}

With the development of commodity production, its monopolization and complication of reproductive processes, the possibilities of regulating market mechanism were limited. In the economy, there are significant disadvantages: a violation of equivalence between aggregate supply and demand, inflation, unemployment. All this mess affects the functioning of business structures. Not all business entities can adjust to that sort of an economic situation. Under 
the conditions, there is an objective need to intensify the role of the state in regulating the economy and functioning of business entities.

The development of entrepreneurship in Ukraine has reached the stage where the improvement of regulatory policy determines its further prospects.

Government regulation of business is a system of legal, organisational, regulatory, and control measures of the state aimed at creating a favourable business environment and managing the public sector to ensure the efficiency and competitiveness of the national economy. Today, Ukraine as an independent, selfsufficient state, guarantees all entrepreneurs (despite their organizational forms of entrepreneurial activity) equal rights and creates the same opportunities for functioning, access to material, technical, financial, labour, information, natural, and other resources upon conditions of execution of works and supplies for state needs. Bodies of the state administration build their relations with entrepreneurs using: a tax and financialcredit system that fixed tax rates and interests on public loans; tax privileges; prices and pricing rules; targeted grants; exchange rate; the amount of economic sanctions; state property and a system of reserves, licenses, concessions, leasing, social, economic and other rules and norms; scientific and technical, social, state and regional programs; agreements for works and supplies for state needs (Buhlak, Zhuravlov, 2016).

The state carries out business regulation through:

- legislative provision of freedom of competition, protection of consumers against unfair competition and monopoly abuse in any spheres of entrepreneurial activity;

- tax and financial-credit policy, including the establishment of tax rates and interest on state loans, tax breaks, prices and pricing rules, exchange rate, size of economic sanctions;

- definition of social norms of enterprise operation, according to which an entrepreneur is obliged to provide respective labour conditions, labour protection, remuneration not lower than the fixed minimum level, as well as other social guarantees, including social and health insurance and social security;

- establishment of environmental norms and standards;

- involvement of entrepreneurs in realising various scientific-technical and economic regional and state programs;

- the conclusion of contracts for the execution of works and the provision of services for state needs.

The main means of regulatory government influence on the activities of business entities are state order; licensing, patenting and fixing quotas; certification and standardization; application of norms and limits; regulation of prices and rates; provision of investment, tax and other incentives; provision of grants-in-aid, compensations, targeted innovations and subsidies
(Cherednychenko, 2014). Successful development of an enterprise is possible only in the context of the security of positive competition, the creation of favourable conditions and sustainable support from the state, effective activity of market mechanisms. Mechanism of government regulation of entrepreneurship is a system of measures elaborated by the state taking into account market requirements and interests of business entities.

Government regulation is performed by the means of the system of norms and measures that prescribe business entities conduct using both administrative methods of influence (laws, decrees, orders, acts, instructions, regulations, etc.) and a system of economic methods and regulators (taxes, prices, bank interest, privileges, sanctions, etc.). Government business regulation has own functions, instruments (methods) and relevant authorities. Instruments, or methods, of government regulation and business support can be divided into economic, administrative, and psychological. Among the administrative methods, the most important and perspective is the regime of the greatest business advancement upon the implementation of a corresponding legal basis, which would not impede the functioning of large business organisations and government enterprises. Economic methods are divided into three groups. Financial methods of entrepreneurial development are soft lending, availability of investment resources, subsidy assistance, joint financing of socially significant projects. Fiscal methods, a reasonable reduction of business rates that contributes to business expansion, are equally relevant. The input method is the development of human resources, including training and retraining of personnel on the basis of state educational programs; information provision, including participation in exhibitions, conferences, fairs and access of business organisations to material resources. Thus, the mechanism of government administration is a complex and system entity, which organically combines various components: economic, motivational, organizational, political, and legal (Prokopets, 2018).

The basis of regulatory and legal support is legislative and other statutory and legal acts, relevant rules of civil, credit and financial, tax, administrative, labour and other branches of the current legislation where the $\mathrm{CC}$ of Ukraine is the main one. State Committee of Ukraine on Regulatory Policy and Entrepreneurship is the central body that ensures the formation and implementation of state policy in the sphere of development and support of entrepreneurship. The main tasks of the body are the development of entrepreneurial policy, the generalization of a practical application of business legislation, elaboration of proposals aimed at its improving. In addition, the Committee promotes the development of small business, the system of consultancy and information support and prepares proposals for the 
implementation and improvement of the mechanisms of financial and credit backing of entrepreneurship and its foreign economic activities, coordinates the system of training and retraining of personnel, etc. Ukraine has a significant number of public organisations, which are aimed at making a contribution to entrepreneurship (Kyrychenko, 2015).

The mechanism of state regulation in Ukraine is enshrined in the Laws "On Protection of Economic Competition", "On Protection against Unfair Competition", "On Advertising", and "On Auditing Activities" in the Code of Ukraine and Civil Code of Ukraine. The regulation of the external economic activity of entrepreneurial organisations is carried out on the basis of the provisions set forth in the Law of Ukraine "On Foreign Economic Activity" which are fundamental for all business entities and should be taken into account during organising of this type of activity.

It is necessary to focus on the means of technical regulation consisting of norms, standards, limits, and standardization system, which is directed to the activity of business entities in order "to achieve an ideal degree of ordering in a particular sphere, the result of which is an increasing degree of conformity of product, processes, and services with their functional purpose, elimination of barriers to trade and promotion of scientific and technological cooperation" (Krehul, Bank, 2016). We can state that the main principles of government support of entrepreneurship are the organizational structures of human resources and scientific and methodological support, as well as the developed market infrastructure and informational and consulting support of entrepreneurship.

Studying the experience of government business regulation in the countries of the European Union (hereinafter referred to as the EU), it is important to emphasize that their concept of supporting small and medium-sized businesses in them is clear and comprehensible. It takes into account national and panEuropean interests, includes goals and principles of that sort of policy and has mechanisms and organizational structuresforitsimplementation. Today, smallbusinesses that are constantly growing in the economy of Great Britain account for $25 \%$ of the total workforce. Italy is recognized as the European leader in this sphere, which has nearly 800 thousand industrial enterprises in the country and $99 \%$ of small and medium-sized enterprises in the total. In Germany and the Netherlands, small and medium-sized businesses provide about $40 \%$ of exports, in Italy - 25-30\%, in France - 20-25\%, and in Japan $10-15 \%$. The main directions of government support for small and medium-sized businesses in EU countries are the formation of the infrastructure for support and entrepreneurship development, the establishment of a system of benefits and a transparent taxation system, the availability of financial and credit support and cooperation with large enterprises, etc. However, it does not mean the creation of "hothouse" conditions for small and medium-sized enterprises, but it is rather a means of balancing the opportunities of small, medium, and large enterprises under the competitive struggle, a way to compensate entrepreneurs' reimbursement for their activities in risky spheres. In the USA, despite the dissemination of idea maximization of the freedom of economic activity, the role of the state in regulating entrepreneurial activity is a significant but ambiguous one. The relations between the state and the business sector have a "wave-like" tendency - from regulation of business activity to its deregulation (that is the reduction of state influence on entrepreneurial activity), which was distributed in the late 1960s and spread in 1970-1980s. Most American scientists point out that at the present stage, the relationship between entrepreneurship and state is antagonistic, and their partnership is considered impossible and harmful to society. At the same time, although business entities take the majority of their decisions on their own, the scope of their activities is reduced, and, accordingly, the sphere of state influence increases. That sort of a tendency to enlargement of the state involvement in the participation in regulating entrepreneurship is becoming widespread and has an ascending trajectory as analysts emphasize.

In regards to Ukraine, it can be noted that the priority of government regulation and support of small and medium-sized enterprises in the information society predetermines the need to switch from direct administrative assistance to the formation of favourable economic and social environment for the improvement of mechanisms and instruments for promoting the development of entities of small and medium-sized enterprises. According to the foreign experience, small enterprises are the most flexible and advantageous for the implementation of scientific and technical, innovation and latest achievements. However, in Ukraine, their share in producing a gross domestic product is much lower than in countries with a developed market economy. The state can contribute to solving this problem by investing a part of the funds received from the privatization of state property in the development of facilities and equipment of entrepreneurship; elaboration and implementation of a mechanism for the transfer of facilities and production capacities to manufacturing enterprise of small enterprises, including those who release in the process of liquidation, reorganization and bankruptcy of enterprises; use of the productive capacity of enterprises under leasing conditions that will enable business organizations to minimize the cost of purchasing fixed capital, and the possibility to deposit a share of business property in their capital stock or its transferring into the economic management of business organisations will increase their security capacity and stability; assistance in the process of formation of a developed real estate market. 


\section{Offences counteraction in the business sphere as a guarantee of the constitutional freedom of a person to conduct entrepreneurial activity in Ukraine}

Analysing the system of subjects countering offences, it should be noted that they form a holistic functional and organizational mechanism, which is characterized by the common purpose and management in the sphere of offenses counteraction. On the one hand, the specificity of the mechanism is conditioned by the multiplicity of functions performed in relation to security, prevention, control, cessation, consideration, investigation, and disclosure of offenses and, on the other hand - by the distribution of tasks among subjects of different levels due to the hierarchical structure of the system for countering offences. This system is a complex social organisation because its groups of similar bodies form relatively independent organizational units that function on the basis of identical laws. Each of these units is a sub-system of a larger system and, at the same time, consists of its sub-systems (Khomko, Kulhavets, 2016).

In addition, we also propose the authorities of public administration, judicial bodies, the whole complex of enterprises, establishments and organizations operating in various spheres of social activity etc. to attribute to the subjects of offences counteraction. However, it is essential to pay attention to the important feature of the mentioned activity. The specified spectrum of functions is carried out by the majority of these bodies along with the solution and accomplishment of other tasks. Execution of the function of counteracting offences is the main type of activity for a relatively small part of such actors. The above bodies have the appropriate rights and duties to influence one or other criminal factors, and due to this reason, they carry out relevant information, methodological, resource, and personnel support.

We mark that some scientists attribute the following ones to subjects of counteraction to offenses: subjects who directly carry out individual prevention; subjects carrying out preventive measures during the performance of their control and law enforcement functions; subjects which are mainly engaged in the management and coordination of activities for the prevention of offenses; and even the Orthodox Church (Bachynskyi, 2018). However, in our opinion, such provisions are quite controversial taking into account the specifics of the issue under consideration.

We also cannot disagree with the standpoints of researchers who identify the President of Ukraine and the Cabinet of Ministers of Ukraine, who "form the legislative and other regulatory and legal bases for offenses prevention, establish competence, rights and duties of other entities of the activity, carry out its financial, personnel, logistical and other resource support, planning, control and other functions of state legal administration in this sphere"; the relevant units of the bodies of internal affairs (now - the National Police Authors), the Security Service of Ukraine, prosecution authorities and other law enforcement agencies with subjects that maintain information and analytical procurement; units of law enforcement authorities with subjects that detect criminal factors. The latter group is the subjects that implement response measures to individual crimes and crime in general.

Summarising the above, it is possible to specify the subjects of counteraction to the offense as follows: public and administrative authorities; local self-government bodies; executive and regulatory bodies; the National Police of Ukraine; Security Service of Ukraine; prosecutor service; courts; general and economic management bodies; informational, statistical, medical, educational and cultural-educational institutions; trade unions, public units of law enforcement, parties, faithbased organisations; services for minors; correctional labour colonies and others like that. Based on this list of actors counteracting the offense, one can also determine the system of their powers. In a short form, the above authorities perform the following tasks and functions in relation to offences prevention:

- to determine the main directions, tasks, forms, and methods of counteracting offenses in the state;

- to carry out informational and analytical provision for counteraction to the offense;

- to detect and inform about criminal factors;

- to carry out response measures directly to individual offenses, as well as measures for elimination, reduction or neutralization of criminal factors including measures for correction of personality deformations and elimination of circumstances that have been caused it (Kasianenko, 2018).

Analysing the concept and essence of the subjects of offences counteraction, one can state that the scope of their powers in this sphere (except for bodies with special focus) is a quite wide and common for many areas of social life of the state and society, and entrepreneurial activity is no exception. Thus, we propose that the subject of offences counteraction in entrepreneurial activity is considered both as a system of government and non-government bodies, public organisations, social groups and citizens whose activities are aimed at eliminating the causes and conditions that result and favour offenses in business commercial activity (entrepreneurship), preventing offenses at different stages of the unlawful behaviour of the participants in the sphere of entrepreneurship, as well as their bringing to legal liability.

It is essential to mark that the range of subjects counteracting offences in entrepreneurial activity is quite broad and to analyse their activities within our study is impossible (Bilousov, 2017). As it was mentioned above, for most of the subjects contracting offences is a task that is carried out along with the main tasks such as the 
generation of a legislative framework and manifestation of initiatives in this sphere, management, control, and supervision over the activities of participants of legal relations in the sphere of economic activity in general and business entities in particular, as well as compliance with relevant legislation. Powers directly related to counteracting offenses in business activities are prescribed to relevant specially established bodies including non-governmental ones.

In addition, according to the CC of Ukraine, control measures over entrepreneurial activity are exercised by state supervision of nuclear and radiation safety (except for state supervision over activities involving sources of ionizing radiation where activities with their use are not subject to licensing), state architectural and construction inspectorate (supervision), state supervision of economic activities for the provision of financial services (except for money transfer operations, financial services in the securities market, derivative securities and the market for banking services), state supervision and control over observance of the legislation on labour and employment of the population in accordance with the procedure established by law and taking into account the peculiarities defined by the laws in the relevant spheres and international agreements, in particular, state supervision (control) in the civil aviation industry taking into account the specifics established by the Air Code of Ukraine, regulatory and legal acts adopted for its implementation (Aviation Rules of Ukraine) and international contracts in the field of civil aviation.

Thus, the system of counteracting the offenses in the entrepreneurial activity is rather numerous and diverse, therefore, we propose to divide the above authorities into several groups depending on such criteria as the form of ownership, the nature of the activity, the complex of powers in the sphere under investigation:

1. State bodies of general competence exercising powers to counteract offenses in the sphere of entrepreneurial activity along with their main functions (the Verkhovna Rada of Ukraine and local selfgovernment bodies, the President of Ukraine and his administration, the Cabinet of Ministers of Ukraine and local state administrations, the Ministry of Finance of Ukraine, the Ministry of Economic Development and Trade of Ukraine; the Ministry of Revenues and Duties of Ukraine; law enforcement agencies (Security Service of Ukraine, the Ministry of Internal Affairs of Ukraine, National Police of Ukraine, Prosecutors Service, etc.), judicial agencies; other central executive bodies that carry out activities to combat offenses in business along with their basic functions).

2. State specialized committees, departments, services, and inspections established directly for the purpose of counteracting offenses in the sphere of entrepreneurial activity (State Fiscal Service of Ukraine, State Financial Inspection of Ukraine, Economy
Protection Department of the National Police of Ukraine, Antimonopoly Committee of Ukraine, State Inspection of Ukraine for Consumer Rights Protection, State Property Fund of Ukraine, State Treasury Service of Ukraine, etc.).

3. Bodies of the financial credit system (National Bank of Ukraine, commercial banks).

4. Non-state actors for business offenses prevention.

It should be noted that some of the above-mentioned state bodies (administrative commissions, rayon, city district, city or city district courts, the National Police of Ukraine, bodies of state financial control, revenue and duties bodies, etc.) can be included into a special group of entities that are endowed with administrative and jurisdictional powers. Their full list is contained in Section III "Bodies authorized to consider cases concerning administrative violations" of the Code of Ukraine on Administrative Offenses (hereinafter referred to as the CUAO). The aforementioned subjects have the right to consider cases of administrative offenses the contents of which are listed in Chapter 12 "Administrative Offenses in the Areas of Trade, Catering, Services, Finance and Business" of the CUAO (Kodeks Ukrainy pro administratyvni pravoporushennia, 1984) and are authorized to bring guilty persons to administrative responsibility.

\section{Conclusions}

The constitutional freedom of a person to conduct the business activity is an economic opportunity of a person on an independent, initiative, systematic, at one's own risk activity for the realization of the right to manufacture, the performance of works, provision of services, trade in order to profit, which is enshrined in the Constitution and is not prohibited and detailed by the laws of Ukraine. Features of constitutional freedom of a person to conduct business activity are as follows: its consolidation in the Constitution and laws of Ukraine; non-restrictive and non-prohibitive nature of human opportunities for entrepreneurial activity; independence, initiative, regularity, risky nature of activity; manufacturer, works performance, provision of services, trading; receiving of profit.

We propose to amend the legislation in the following way: a) in Art. 42 Part 1 of the Constitution of Ukraine, to add "Freedom of enterprise in Ukraine is guaranteed" and further as the text goes before the words "Everyone has the right to carry out entrepreneurial activity" ... (Konstytutsiia Ukrainy); b) in Art. 43 of the Commercial Code of Ukraine, to consolidate "entrepreneurs have the right" and further as the text goes instead of the words "entrepreneurs are guaranteed freedom". The implementation of the proposed changes and recommendations will facilitate improving the realisation of the constitutional freedom of an individual to conduct entrepreneurial activities. 
Under modern conditions, entrepreneurial activity needs a detailed legislative regulation, which is intended to promote the further development of both the various forms of entrepreneurship and the economy of Ukraine as a whole. To date, there is no special regulatory act that would establish the legal status of a citizen-entrepreneur and objective prohibitions and restrictions on the implementation of the entrepreneurial activity. Therefore, a new legal act must be adopted that would consolidate the relevant status and peculiarities of the management of a private entrepreneur as a business entity. It would be expedient to fix the list of activities where the entrepreneurship is prohibited in Art. 128 of the CC of Ukraine.

\section{References:}

Vinnyk, O. M. (2017). Hospodarske pravo: kurs lektsii (zahalna chastyna) [Commercial law: series of lectures (general part)]. Kyiv: Lira-K. (in Ukrainian)

Hospodarskyi kodeks Ukrainy: Zakon Ukrainy vid 16 sichnia 2003 r. № 436-IV [Commercial Code of Ukraine: the Law of Ukraine: the Law of Ukraine dated January 16, 2003 No 436-IV]. Retrieved from: https:/ /zakon.rada.gov.ua/ go/436-15

Pro fermerske hospodarstvo: Zakon Ukrainy vid 19 chervnia 2003 r. № 973-IV [On farming: the Law of Ukraine dated January 19, 2003 No 973-IV]. Retrieved from: https://zakon.rada.gov.ua/go/973-15

Konstytutsiia Ukrainy vid 28 chervnia 1996 r. № 254k/96-VR [The Constitution of Ukraine dated June 28, 1996 No 254к/96-BP]. Retrieved from: http://www.zakon.rada.gov.ua/go/254к/96-вр

Pro pidpryiemnytstvo: Zakon Ukrainy vid 7 liutoho 1991 r. № 698-XII [On entrepreneurial activity: the Law of Ukraine dated February 7, 1991 № № 698-XII]. Retrieved from: https://zakon.rada.gov.ua/go/698-12

Buhlak, Yu. O., Zhuravlov, D. V. (2016). Administratyvno-pravovi zasady detinizatsii vidnosyn u pidpryiemnytskii diialnosti: monohrafiia [Administrative and legal principles of the shadowing of relations in entrepreneurial activity: a monograph]. Kyiv: Helvetica. (in Ukrainian)

Cherednychenko, H. A. (2014). Mekhanizm derzhavnoho rehuliuvannia pidpryiemnytskoi diialnosti v Ukraini ta napriamy yoho vdoskonalennia [The mechanism of state regulation of entrepreneurial activity in Ukraine and directions of its improvement.]. Economics and management: problems of science and practice: Collection of scientific articles, 1, 162-167.

Prokopets, L. V. (2018). Mekhanizmy derzhavnoho rehuliuvannia pidpryiemnytskoi diialnosti [Mechanisms of state regulation of entrepreneurial activity]. Biznes-navihator, 1-1, 162-166.

Kyrychenko, Yu. V. (2015). Konstytutsiine rehuliuvannia prava na pidpryiemnytsku diialnist v Ukraini ta derzhavakh kontynentalnoi Yevropy [Constitutional regulation of the right to entrepreneurial activity in Ukraine and the states of continental Europe]. Naukovyi visnyk Khersonskoho derzhavnoho universytetu. Seriia: Yurydychni nauky, 5(1), 75-79.

Krehul, Yu. I., Bank, R. O. (2016). Bezpeka pidpryiemnytskoi diialnosti v Ukraini: administratyvno-pravovyi aspekt: monohrafiia [Security of entrepreneurship in Ukraine: administrative and legal aspect: a monograph]. Kyiv: Kyiv. nats. torh.-ekon. un-t. (in Ukrainian)

Khomko, L. V., Kulhavets, Kh. Yu. (2016). Pravove rehuliuvannia pidpryiemnytskoi diialnosti: navchalnyi posibnyk [Legal regulation of entrepreneurship: a textbook]. Lviv: LvDUVS. (in Ukrainian)

Bachynskyi, A. Ya. (2018). Mekhanizmy derzhavnoho rehuliuvannia pidpryiemnytskoi diialnosti v Ukraini [Mechanisms of state regulation of entrepreneurial activity in Ukraine]. Vcheni zapysky Tavriiskoho natsionalnoho universytetu imeni V. I. Vernadskoho. Seriia: Derzhavne upravlinnia, 29(68), no. 2, 52-55.

Kasianenko, D. I. (2018). Osoblyvosti hospodariuvannia fizychnoi osoby yak subiekta pidpryiemnytskoi diialnosti [Features of management of a private entrepreneur as a business entity]. Molodyi vchenyi, 10(2), 659-662.

Bilousov, Ye. M. (2017). Aktualni problemy hospodarsko-pravovoho zabezpechennia ekonomichnoi bezpeky Ukrainy: monohrafiia [Actual problems of economic and legal provision of economic security of Ukraine: monograph]. Kharkiv: Pravo. (in Ukrainian)

Kodeks Ukrainy pro administratyvni pravoporushennia: Zakon Ukrainy vid 7 hrudnia 1984 r. № 8073-X [Code of Ukraine on Administrative Offences: the Law of Ukraine dated December 7, 1984 No 8073-X]. Retrieved from: http://www.zakon.rada.gov.ua/go/80731-10 